\title{
UJI AKTIVITAS ANTIOKSIDAN, SITOTOKSISITAS DAN GC-MS EKSTRAK METANOL ALGA HIJAU Boergesenia Forbesii (HARVEY) FELDMANN DARI PANTAI PANJANG BENGKULU
}

\author{
Putjha Melati \\ Universitas Bengkulu \\ Korepondensi: putjha.m@unib.ac.id
}

\begin{abstract}
Abstrak
Penelitian tentang aktivitas antioksidan, sitotoksisitas, dan GC MS ekstrak metanol alga hijau Boergesenia forbesii (Harvey) Feldmann telah dilaksanakan. Uji aktivitas antioksidan dilakukan dengan metode DPPH (1,1-diphenyl-2-picrylhydrazil). Uji sitotoksisitas terhadap Artemia salina Leach dilakukan dengan metode BSLT (Brine Shrimp Lethality Test). Identifikasi komponen kimia ekstrak dilakukan dengan menggunakan GC MS. Hasil uji menunjukkan bahwa ekstrak metanol alga hijau Boergesenia forbesii memiliki aktivitas antioksidan sangat lemah $\left(\mathrm{IC}_{50}=\right.$ 585,79ppm). Uji sitotoksisitas terhadap Artemia salena Leach menunjukkan bahwa ekstrak berkolerasi positif sebagai anti kanker $\left(\mathrm{LC}_{50}=508,74 \mathrm{ppm}\right)$. Berdasarkan analisis GC MS dari ekstrak metanol alga hijau Boergesenia forbesii menunjukkan 28 senyawa. Komponen utama dari ekstrak metanol alga hijau Boergesenia forbesii adalah Methyl Stearate, Phytol, Methyl Arachidonate, dan 9-Octadecenamide,(z)-.
\end{abstract}

Kata Kunci: Antioksidan, Sitotoksisitas, GC MS, DPPH, Boergesenia forbesii

\section{Abstract}

Research on the antioxidant activity, cytotoxicity assays and GC MS Analysis of Boergesenia forbesii (Harvey) Feldmann methanol extract has been carried out. Antioxidant activity assay was conducted using DPPH (1,1-diphenyl-2picrylhydrazil) method. Citotoxicity assay against Artemia salina Leach was peformed using the BSLT (Brine shrimp Letharity Test) method. The results showed that methanol extract of Boergesenia forbesii (Harvey) Feldmann had low antioxidative activity $\left(\mathrm{IC}_{50}=585,79 \mathrm{ppm}\right)$. Cytotoxicity assay against Artemia salina Leach showed that the methanol extract belonged to the toxic group or have positive correlated as anticancer $\left(\mathrm{LC}_{50}=508,74 \mathrm{ppm}\right)$. GC-MS analysis of the methanol extract of Boergesenia forbesii showed 28 compounds. The major ones are Methyl Stearate, Phytol, Methyl Arachidonate, dan 9-Octadecenamide, (z)-.

Keywords: Antioxidant, Citotoxicity, GC MS, DPPH, Boergesenia forbesii

\section{PENDAHULUAN}

Kota Bengkulu memiliki pantai dengan panjang sekitar $7 \mathrm{~km}$ dan lebar pantai dari garis pasang dan garis surut sekitar $500 \mathrm{~m}$, pantai ini diberi nama Pantai Panjang (https://pariwisata.bengkuluprov.go.id, 2018). Disekitar kawasan tepi pantai merupakan tempat pariwisata dan juga pemukiman nelayan. Berdasarkan keadaan geografis Kota Bengkulu yang memiliki sebagian besar daerah pesisir dan laut membentang luas ke Samudra Hindia, menyebabkan begitu banyaknya keanekaragaman biota laut, salah satunya adalah alga. 
Alga sudah sejak zaman dahulu secara tradisional digunakan sebagai obat ataupun sebagai suplemen oleh masyarakat (Wikanta et al., 2005), diantaranya digunakan sebagai obat penyakit penurun panas, eksim, gangguan ginjal, gangguan empedu dan anticurare (Wikanta et al., 2008). Potensi alga sebagai obat atau sebagai suplemen dibidang kesehatan hingga kini terus dikembangkan. Alga memiliki kandungan senyawa aktif seperti senyawa polifenol, fenol, flavonoid (Kuda et al., 2007), terpenoid, tanin, fukoidan, sterol, dan glikolipid (Chakraborty dan Paulraj, 2010). Senyawa tersebut memiliki manfaat untuk kesehatan manusia (Kuda et al., 2007), diantaranya sebagai antikanker, antibakteri, antijamur, antivirus (Chakraborty dan Paulraj, 2010) dan antioksidan (Wu et al., 2010). Menurut Zubia et al., (2007) antioksidan alami dari alga memiliki peran penting untuk mengobati berbagai penyakit seperti sitotoksik dan mencegah proses penuaan dini. Hal ini juga dilaporkan oleh Tamat et al., (2007) fungsi dari antioksidan adalah mencegah penyakit degeneratif seperti kanker, tumor, penuaan dini, osteoporosis, jantung dan artherosclerosis.

Antioksidan merupakan senyawa yang dapat menghambat reaksi oksidasi (electron donor), dengan mengikat radikal bebas dan molekul yang sangat reaktif, akibatnya kerusakan pada sel akan dihambat. Secara biologis antioksidan adalah senyawa yang memiliki kemampuan untuk menangkap senyawa radikal bebas (senyawa yang tidak memiliki pasangan elektron) yang bisa berdampak negatif dalam tubuh (Winarsi, 2007). Adapun mekanisme kerja antioksidan salah satunya yaitu dengan cara menyumbangkan elektron, sehingga dapat menetralkan radikal bebas yang akan mengoksidasi molekul biologis yang bisa menyebabkan kematian atau kerusakan sel dan jaringan (Ozben, 2007).

Uji sitotoksisitas suatu senyawa dapat dilakukan dengan metode Brine Shrimp Lethality Test (BSLT). Metode BSLT dilakukan untuk melihat efek sitotoksisitas terhadap sel dan sering digunakan dalam uji pendahuluan untuk skrining atau penapisan aktivitas farmakologis pada tanaman obat dan juga banyak digunakan untuk skrining senyawa antikanker baru yang berasal dari tanaman (Tamat et al., 2007). Hasil uji toksisitas dengan metode ini telah terbukti memiliki korelasi positif dengan daya sitotoksik senyawa antikanker. Selain itu, metode ini juga mudah dikerjakan, murah, cepat dan akurat (Meyer et al., 1982).

Alga digolongkan menjadi 3 (tiga) golongan besar berdasarkan kandungan kimia dan warnanya, yaitu Chlorophyta (alga hijau), Rhodophyta (Alga Merah), dan Phaeophyta (Alga coklat) (Gupta dan Abu-Ghannam, 2011). Boergesenia forbesii (Harvey) Feldman merupakan salah satu alga hijau yang termasuk kedalam kelas Ulvophyceae (M.D. Guiry dalam Guiry dan Guiry, 2018).

Beberapa golongan genus dan spesies alga hijau, alga merah, dan alga coklat telah dilaporkan mengandung senyawa aktif yang memiliki aktivitas antioksidan (Cox et al., 2010), diantaranya Gracilaria (Saeidnia et al., 2012), Halymena, Padina, Turbinaria, Ahnfeltiopsis, Colpomenia, Hydroclathrus, Laurencia, Polysiphonia (Cornish dan Garbary, 2010), Euchema sp (Rosalina dan Andrew, 2009), Ulva fasciata (Marraskuranto et al., 2008), dan Sargassum sp. (Budhiyanti et al., 2012).

Sudah banyak dilakukan penelitian alga hijau sebagai antioksidan (Heo et al., 2005) dikarenakan alga hijau pada umumnya mengandung senyawa fenol, flavonoid, asam askorbat, dan glutanin (Wu et al., 2010) seperti pada alga hijau Ulva Fasciata (Chakraborty et al., 2010) dan (Marraskunto et a.l, 2008) dan alga hijau Ulva reticulata (Tamat et al., 2007), alga tersebut merupakan satu kelas dengan alga hijau Boergesenia forbesii (Harvey) Feldmann dalam tingkatan taksonomi, sehingga diduga alga hijau Boergesenia forbesii (Harvey) Feldmann juga memiliki kandungan senyawa aktif sebagai antioksidan. 
Alga hijau Boergesenia forbesii (Harvey) Feldmann terdapat di perairan Pantai Panjang Kota Bengkulu dan telah dilaporkan dalam penelitian Syarifuddin dan Supriati, R (2009). Belum ada penelitian sebelumnya tentang potensi antioksidan dan aktivitas sitotoksik alga hijau Boergesenia forbesii (Harvey) Feldmann yang berasal dari perairan Pantai Panjang Kota Bengkulu. Oleh karena itu, penelitian mengenai alga hijau Boergesenia forbesii (Harvey) Feldmann sebagai antioksidan alami ingin dilakukan sebagai bentuk mengoptimalisasikan potensi alga yang ada di Pantai Panjang Kota Bengkulu.

\section{METODE PENELITIAN}

Alat

Alat yang digunakan rotary evaporator (Heidolph), spektrofotometer UV-Vis (ThermoScientific), GC-MS (Gas Chromatography-Mass Spectrofotmetry) (Shimadzu), refrigerator (Dometic), timbangan analitik (Bel Engineering), vortek (JeioTech), mikropipet, alat-alat gelas seperti tabung reaksi, gelas kimia, gelas ukur, corong pisah, batang pengaduk, cawan petri, botol sampel, botol maserasi dan botol vial. Kemudian alat lain yang digunakan juga seperti baskom, pinset, spatula, mikropipet dan rak tabung reaksi.

\section{Bahan}

Bahan yang digunakan metanol (Sigma Aldrich), DPPH (1,1- phenil-2-pikrilhidrazil) (Sigma Aldrich), aquadest (Teknis), DMSO, asam galat (Sigma Aldrich), kapas steril, air laut, dan aluminium foil.

\section{Bahan Uji}

Sampel segar Alga Hijau Boergesenia forbesii (Harvey) Feldmann diambil di kawasan pantai Malabero Pantai Panjang Bengkulu dan Hewan uji larva Artemia salina Leach didapatkan dengan membeli online di Tokopedia.

Prosedur Penelitian

\section{Pengambilan sampel}

Sampel segar alga hijau Boergesenia forbesii (Harvey) Feldmann diperoleh dari pesisir pantai Malabero, Pantai Panjang kota Bengkulu dapat dilihat pada Gambar 7. Alga diambil pada saat air laut surut, kemudian alga yang telah diambil dibersihkan dengan menggunakan air laut. Setelah itu, alga dimasukkan ke dalam plastik yang berisi air laut, dan dibawa ke Laboratorium FKIK UNIB untuk disimpan didalam refrigerator.

\section{Preparasi Alga Hijau Boergesenia forbesii (Harvey) Feldmann}

Alga hijau Boergesenia forbesii (Harvey) Feldman dikeluarkan dari refrigerator, kemudian alga dicuci bersih dengan menggunakan air aquadest dengan cara dialirkan. Alga ditimbang, didapatkan sebanyak $1 \mathrm{~kg}$. Alga dimasukkan kedalam wadah dan dipisahkan dari cairannya. Alga yang sudah dipisahkan dari cairannya ditimbang kembali dan disimpan di refrigerator untuk proses selanjutnya.

\section{Ektraksi Alga Hijau Boergesenia forbesii (Harvey) Feldmann}

Ektraksi sampel segar Boergesenia forbesii (Harvey) Feldmann dilakukan dengan metode maserasi menggunakan pelarut metanol. Sampel segar Boergesenia forbesii (Harvey) Feldmann yang sudah dipisahkan dari cairannya sebanyak 500 gram di masukkan ke dalam wadah kaca gelap kemudian dimasukkan pelarut metanol sebanyak 1,5 liter atau alga sampai terendam oleh pelarut. Maserasi dilakukan berulang-ulang sampai didapatkan hasil akhir ekstrak metanol berwarna jernih. Ekstrak metanol yang 
diperoleh disaring dengan kapas steril. Ekstrak metanol yang telah disaring diuapkan pelarutnya menggunakan rotary evaporator sampai metanol benar-benar menguap pada suhu $50{ }^{\circ} \mathrm{C}$. Ekstrak metanol kental yang diperoleh selanjutnya disimpan didalam refrigerator pada suhu $4{ }^{\circ} \mathrm{C}$.

\section{Pembuatan Larutan Induk DPPH}

Ditimbang serbuk DPPH sebanyak 2,5 mg kemudian dilarutkan dengan menambahkan metanol sampai tanda batas $50 \mathrm{ml}$ pada labu ukur, sehingga didapatkan larutan DPPH dengan konsentrasi 50 ppm (Tristantini, 2016).

\section{Pembuatan Larutan Induk Ekstrak Metanol Alga Hijau Boergesenia forbesii} (Harvey) Feldmann

Sampel ekstrak metanol Boergesenia forbesii (Harvey) Feldman ditimbang sebanyak $5 \mathrm{mg}$, kemudian dilarutkan dengan menambahkan $5 \mathrm{~mL}$ metanol sampai tanda batas pada labu ukur, sehingga diperoleh larutan dengan konsentrasi 1000 ppm (larutan induk). Larutan induk akan digunakan selanjutnya untuk membuat variasi konsentrasi ekstrak metanol Boergesenia forbesii (Harvey) Feldman yang akan diuji aktivitas antioksidannya.

\section{Pembuatan Konsentrasi Sampel Ekstrak Metanol Alga Hijau Boergesenia} forbesii (Harvey) Feldmann

Larutan induk sampel ekstrak metanol alga hijau Boergesenia forbesii (Harvey) Feldmann (1000 ppm) dipipet sebanyak 62,5 $\mu \mathrm{L}, 125 \mu \mathrm{L}, 250 \mu \mathrm{L}, 500 \mu \mathrm{L}, 1000 \mu \mathrm{L}$ kemudian masing-masing dimasukkan ke dalam labu ukur $5 \mathrm{ml}$, dan ditambahkan metanol sampai tanda batas. Sehingga didapatkan konsentrasi masing-masing sampel 12,5 ppm, 25 ppm, 50 ppm, 100 ppm dan 200 ppm.

\section{Pembuatan Larutan Kontrol Positif Asam Galat}

Ditimbang serbuk asam galat sebanyak $5 \mathrm{mg}$ kemudian dilarutkan dengan menambahkan metanol sampai tanda batas $25 \mathrm{~mL}$ pada labu ukur, sehingga didapatkan konsentrasi larutan induk asam galat $100 \mathrm{ppm}$. Larutan induk asam galat dipipet sebanyak $25 \mu \mathrm{L}, 37,5 \mu \mathrm{L}, 50 \mu \mathrm{L}, 62,5 \mu \mathrm{L}$, dan $75 \mu \mathrm{L}$ kemudian masing-masing dimasukkan ke dalam labu ukur $5 \mathrm{ml}$ dan ditambahkan metanol sampai tanda batas. Sehingga didapatkan konsentrasi asam galat (kontrol positif) 0,50 ppm, 0,75 ppm, $1 \mathrm{ppm}, 1,25 \mathrm{ppm}$, dan 1,50 ppm.

\section{Uji Antioksidan}

Uji antioksidan menggunakan metode DPPH, yaitu menguji potensi aktivitas antioksidan senyawa dalam ekstrak metanol alga hijau Boergesenia forbesii (Harvey) feldmann, yang berdasarkan pada prinsip reaksi penangkapan hidrogen dari antioksidan oleh radikal bebas Difenil dikril hidrazil (DPPH). Konsentrasi sampel ekstrak metanol alga hijau Boergesenia forbesii (Harvey) Feldmann yang digunakan adalah 12,5 ppm, 25 ppm, 50 ppm, 100 ppm dan 200 ppm. Masing-masing konsentrasi diambil $1 \mathrm{~mL}$ dan dimasukkan ke dalam tabung, kemudian masing-masing tabung ditambahkan larutan DPPH 50 ppm sebanyak $1 \mathrm{ml}$ (Tristantini, 2016). Setelah homogen, diinkubasikan dalam ruang gelap dengan suhu ruang selama 30 menit. Absorbansi diukur dengan menggunakan spektrofotometer UV-Vis pada panjang gelombang $515 \mathrm{~nm}$ (Wikanta et al., 2005). Setiap konsentrasi dilakukan 3 kali pengulangan. Asam galat digunakan sebagai pembanding (kontrol positif) dengan menggunakan konsentrasi 0,50 ppm, 0,75 ppm, 1 ppm, 1,25 ppm dan $1,75 \mathrm{ppm}$. Sedangkan untuk kontrol negatif menggunakan campuran larutan metanol $1 \mathrm{ml}$ dan DPPH 50 ppm $1 \mathrm{ml}$. Kontrol positif diuji dengan perlakuan yang sama dengan pengujian sampel. Kemampuan untuk menghambat radikal bebas DPPH (inhibisi) 
dihitung dengan menggunakan rumus persamaan sebagai berikut (Miliauskas et al., 2004):

$$
\% \text { Inhibisi }=\frac{(A-B)}{A} \times 100
$$

Keterangan :

$\mathrm{A}=$ absorbansi kontrol negatif larutan $\mathrm{DPPH}$

$\mathrm{B}=$ absorbansi ekstrak/fraksi dan DPPH

Nilai $\mathrm{IC}_{50}$ (Inhibition Concentration) diperoleh dari perpotongan garis antara persen hambatan (sebagai sumbu y) dan konsentrasi (sebagai sumbu x), kemudian dimasukkan ke dalam persamaan $\mathrm{y}=\mathrm{a}+\mathrm{bx}$. Dimana $\mathrm{y}=50$ dan nilai $\mathrm{x}$ menunjukkan IC50 (Miliauskas et al., 2004).

\section{Uji Sitotoksisitas dengan Metode BSLT}

Metode Brine Shrimp Lethality Test (BSLT) dilakukan dengan mengamati tingkat kematian (mortalitas) yang ditimbulkan oleh ekstrak terhadap larva udang jenis Artemia salina Leach setelah dilakukan pengujian selama 24 jam. Metode ini dipilih karena mudah dilakukan, sederhana, memiliki spektrum aktivitas farmakologi yang luas, cepat, memiliki tingkat kepercayaan 95\%, dan tidak memerlukan biaya besar (Meyer et al., 1982). Uji sitotoksisitas dilakukan berdasarkan metode Meyer et al., (1982), Mclaughlin et al., (1998) dan Carballo et al., (2002) dengan larva Artemia salina Leach sebagai hewan uji. Mula-mula telur A. salina Leach ditetaskan di dalam air laut yang sudah disaring dari kotoran. Setelah 48 jam, telur menetas menjadi nauplii instar III/IV dan siap digunakan sebagai hewan uji. Larva $A$. salina Leach dimasukkan ke dalam tabung yang telah berisi larutan ekstrak metanol alga hijau Boergesenia forbesii (Harvey) Feldmann dengan konsentrasi 0 ppm (kontrol), 10 ppm, 100 ppm, dan 1000 ppm dengan 3 kali pengulangan. Semua tabung diinkubasi pada suhu kamar selama 24 jam dibawah penerangan lampu TL 20 watt. Pengamatan dilakukan setelah 24 jam dengan melihat jumlah Artemia salina Leach yang mati pada tiap konsentrasi. Kematian larva pada tiap konsentrasi kemudian dihitung $\%$ mortalitas dengan rumus berikut:

$\%$ Mortalitas $=\frac{\text { Jumlah larva yang mati }}{\text { Jumlah total larva uji }} \times 100 \%$ (Nurhayati, 2006)

Dengan mengetahui kematian larva Artemia salina, kemudian dicari angka probit melalui tabel dan dibuat persamaan garis: $\mathrm{Y}=\mathrm{Bx}+\mathrm{A}$ dimana $\mathrm{Y}=\log$ konsentrasi, dan $\mathrm{X}$ $=$ Angka probit. Penentuan harga $\mathrm{LC}_{50}$ dalam $\mu \mathrm{g} / \mathrm{ml}$ atau ppm dilakukan menggunakan analisis probit, yaitu dengan menghitung Antilog dari nilai x yang diperoleh (Meyer et al., 1982).

\section{Identifikasi senyawa bioaktif dengan GC-MS}

Identifikasi dilakukan untuk menentukan profil senyawa antioksidan dalam alga hijau Boergesenia forbesii (Harvey) Feldmann dengan menggunakan GC-MS (QP2010S SHIMADZU) terhadap ekstrak metanol B. forbesii. Hasil yang didapatkan berupa kromatogram yang ditunjukkan dengan satu grafik dengan beberapa puncak. Setiap satu puncak yang muncul merupakan satu jenis senyawa. Sampel diinjeksikan ke dalam kolom yang berukuran $30 \mathrm{~m}$ x 0,25 mm i.d dengan film tipis $0,25 \mu \mathrm{M}$. Helium digunakan sebagai gas pembawa dengan laju alir $1 \mathrm{ml} /$ menit, injektor dioperasikan pada suhu $200{ }^{\circ} \mathrm{C}$ dan suhu kolom oven di program di suhu $50-250{ }^{\circ} \mathrm{C}$ pada kecepatan $10{ }^{\circ} \mathrm{C} /$ menit mode injeksi. Berikut kondisi MS yang digunakan: Voltase ionisasi $70 \mathrm{eV}$; temperatur sumber ion pada $250{ }^{\circ} \mathrm{C}$; mass range dari 50-600. Diperoleh kromatogram dan spektrum massa 
dari senyawa yang belum diketahui kemudian dibandingkan dengan spektrum dari senyawa yang sudah diketahui yang terdapat pada NIST library (Maheswari et al., 2017).

\section{HASIL DAN PEMBAHASAN}

\section{Uji Antioksidan}

Uji aktivitas antioksidan pada penelitian ini menggunakan metode DPPH dengan pengukuran absorbansi pada spektrofotometer UV Vis. Pengujian dilakukan dengan menggunakan panjang gelombang $515 \mathrm{~nm}$, dikarenakan senyawa DPPH dalam metanol berwarna ungu tua yang terdeteksi pada panjang gelombang sinar tampak di sekitar 515$517 \mathrm{~nm}$ (Molyneux, 2004).

Hasil pengujian aktivitas antioksidan asam galat (kontrol positif) dan ekstrak metanol alga hijau Boergesenia forbesii dapat dilihat pada Tabel 1 dan 2.

Tabel 1. Aktivitas antioksidan asam galat (kontrol positif) terhadap DPPH

\begin{tabular}{llcc}
\hline \hline No & $\begin{array}{c}\text { Konsentrasi Asam Galat } \\
\text { (ppm) }\end{array}$ & Absorban & $\begin{array}{c}\text { Aktivitas } \\
\text { Antioksidan (\%) }\end{array}$ \\
\hline \hline 1 & 0,5 & 0,901 & 7,11 \\
\hline 2 & 0,75 & 0,864 & 10,93 \\
\hline 3 & 1 & 0,816 & 15,88 \\
\hline 4 & 1,25 & 0,788 & 18,76 \\
\hline 5 & 1,5 & 0,741 & 23,61 \\
\hline
\end{tabular}

Tabel 2. Aktivitas antioksidan ekstrak metanol alga hijau Boergesenia forbesii terhadap DPPH

\begin{tabular}{cccc}
\hline No & $\begin{array}{c}\text { Konsentrasi Ekstrak } \\
\text { metanol B. forbesii } \\
(\mathbf{p p m})\end{array}$ & Absorban & $\begin{array}{c}\text { Aktivitas Antioksidan } \\
(\mathbf{\%})\end{array}$ \\
\hline 1 & 12,5 & 0,923 & 4,85 \\
\hline 2 & 25 & 0,886 & 8,66 \\
\hline 3 & 50 & 0,845 & 12,89 \\
\hline 4 & 100 & 0,814 & 16,08 \\
\hline 5 & 200 & 0,774 & 20,21 \\
\hline \hline
\end{tabular}

Berdasarkan Tabel 1 dan 2, menunjukkan bahwa semakin besar konsentrasi asam galat dan ekstrak metanol alga hijau Boergesenia forbesii, maka semakin kecil nilai absorbansi yang diperoleh. Terjadinya penurunan nilai absorbansi ini dikarenakan adanya penangkapan radikal bebas pada DPPH oleh asam galat dan ekstrak metanol alga hijau Boergesenia forbesii sehingga berbanding terbalik dengan nilai $\%$ aktivitas antioksidannya.

Dengan adanya senyawa aktif antioksidan dalam suatu ekstrak, akan mengubah warna ungu DPPH menjadi warna kuning-coklat (Molyneux, 2004). Hal ini dikarenakan terjadinya reaksi antara antioksidan dengan radikal bebas yang berdasarkan prinsip reaksi penangkapan hidrogen dari antioksidan oleh radikal bebas DPPH. Antioksidan mendonorkan proton atau hidrogen kepada DPPH, sehingga terbentuk radikal bebas baru yang bersifat lebih stabil atau tidak reaktif. Penangkapan radikal DPPH oleh antioksidan dapat diamati dengan terjadinya penurunan absorbansi pada $515 \mathrm{~nm}$ (Wikanta, 2005). Hal ini dapat di ilustrasikan dalam persamaan berikut:

$\mathrm{DPPH}^{*}+\mathrm{AH} \longrightarrow \mathrm{DPPH}-\mathrm{H}+\mathrm{A}^{*}$

Radikal bebas AntioksidanNetral Radikal Bebas

\section{Baru}


Berdasarkan data pada Tabel 2 dan 3, maka didapatkan masing-masing persamaan regresi linier dari grafik aktivitas antioksidan asam galat (kontrol positif) dan ekstrak metanol alga hijau Boergesenia forbesii pada berbagai konsentrasi terhadap DPPH. Grafik aktivitas antioksidan asam galat dan ekstrak metanol alga hijau Boergesenia forbesii pada berbagai konsentrasi terhadap DPPH dapat dilihat pada Gambar 1 dan 2.

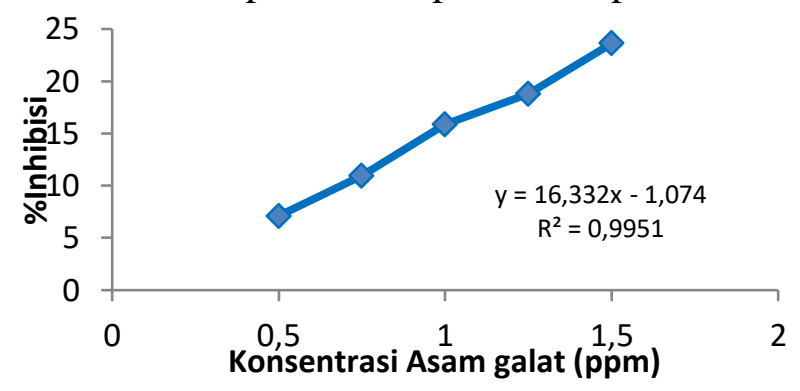

Gambar 1. Grafik aktivitas antioksidan asam galat (kontrol positif) dengan berbagai konsentrasi terhadap DPPH

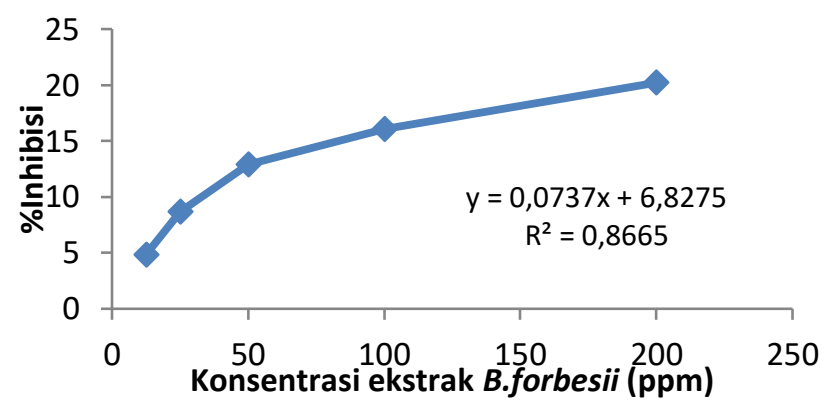

Gambar 2. Grafik aktivitas antioksidan ekstrak metanol B. forbesii dengan berbagai konsentrasi terhadap DPPH

Berdasarkan grafik pada Gambar 1 dan 2, maka didapatkan persamaan regresi linier y $=16,332 \mathrm{x}-1,074$ untuk asam galat (kontrol positif), dan persamaan regresi linier $\mathrm{y}=$ $0,0737 x+6,8275$ untuk ekstrak metanol alga hijau $B$. forbesii. Dari masing-masing persamaan regresi linier yang diperoleh tersebut, maka dapat dihitung nilai IC $_{50}$ (Inhibition Concentration). Nilai $\mathrm{IC}_{50}$ adalah konsentrasi ekstrak yang mampu mereduksi aktivitas radikal bebas (DPPH) sebesar 50\% (Molyneux, 2004). Nilai IC 50 yang diperoleh dapat dilihat pada Tabel 3 .

Tabel 3. Nilai IC $_{50}$ pada asam galat (kontrol positif) dan ekstrak metanol alga hijau Boergesenia forbesii.

\begin{tabular}{clc}
\hline \hline No & \multicolumn{1}{c}{ Sampel } & Nilai IC $_{\mathbf{5 0}}$ (ppm) \\
\hline 1 & Asam Galat (kontrol positif) & 3,13 \\
\hline 2 & Ekstrak metanol alga hijau Boergesenia forbesii & 585,79 \\
\hline \hline
\end{tabular}

Dari Tabel 3 diatas, nilai $\mathrm{IC}_{50}$ pada asam galat menunjukkan bahwa 50\% radikal bebas DPPH berhasil dihambat oleh asam galat pada konsentrasi 3,13 ppm, sedangkan 50\% radikal bebas DPPH berhasil dihambat oleh ekstrak metanol alga hijau Boergesenia 
forbesii pada konsentrasi 585,79 ppm. Menurut Lu (2014), melaporkan $\mathrm{IC}_{50}$ asam galat pada konsentrasi $10 \mathrm{ppm}$ sebesar $1,50 \mathrm{ppm}$. Hal ini tidak berbeda jauh dengan hasil $\mathrm{IC}_{50}$ asam galat dalam penelitian ini. Perbedaan nilai $\mathrm{IC}_{50}$ ini dikarenakan adanya perbedaan konsentrasi yang digunakan. Berdasarkan hasil $\mathrm{IC}_{50}$ tersebut, menunjukkan bahwa aktivitas antioksidan ekstrak metanol alga hijau Boergesenia forbesii jauh lebih rendah dibandingkan asam galat sebagai pembanding (kontrol positif). Maka ekstrak metanol alga hijau Boergesenia forbesii memiliki aktivitas antioksidan dengan kategori yang sangat lemah.

\section{Hasil Uji Sitotoksisitas dengan Menggunakan Metode BSLT (Brine Shrimp Lethality Test)}

Untuk menentukan aktivitas sitotoksik dari ekstrak metanol alga hijau Boergesenia forbesii digunakan metode Brine Shrimp Lethality Test (BSLT). Pengujian BSLT menggunakan larva Artemia Salina Leach yang telah ditetaskan terlebih dahulu selama 48 jam didalam air laut. Data hasil pengujian BSLT ekstrak metanol alga hijau Boergesenia forbesii terhadap larva udang Artemia salina Leach dapat dilihat pada Tabel 4.

Tabel 4. Data Mortalitas pengujian BSLT ekstrak metanol alga hijau Boergesenia forbesii terhadap larva udang Artemia salina Leach.

\begin{tabular}{|c|c|c|c|c|c|c|c|c|}
\hline No & $\begin{array}{c}\text { Konsentrasi } \\
(\text { ppm) }\end{array}$ & $\begin{array}{c}\text { Log } \\
\text { Konsentrasi }\end{array}$ & Ulangan & $\begin{array}{l}\text { Total } \\
\text { Larva }\end{array}$ & $\begin{array}{c}\text { Jumlah } \\
\text { larva } \\
\text { yang } \\
\text { mati } \\
\end{array}$ & $\begin{array}{c}\% \\
\text { mortalitas }\end{array}$ & $\begin{array}{l}\text { Rata-rata } \\
\text { mortalitas }\end{array}$ & $\begin{array}{l}\text { Nilai } \\
\text { Probit }\end{array}$ \\
\hline 1 & 0 & - & 1 & 10 & 0 & 0 & \multirow{3}{*}{0} & \\
\hline 2 & 0 & - & 2 & 10 & 0 & 0 & & - \\
\hline 3 & 0 & - & 3 & 10 & 0 & 0 & & \\
\hline 4 & 10 & 1 & 1 & 10 & 0 & 0 & \multirow{3}{*}{3,33} & \multirow{3}{*}{3,1616} \\
\hline 5 & 10 & 1 & 2 & 10 & 1 & 10 & & \\
\hline 6 & 10 & 1 & 3 & 10 & 0 & 0 & & \\
\hline 7 & 100 & 2 & 1 & 10 & 0 & 0 & \multirow{3}{*}{3,33} & \multirow{3}{*}{3,1616} \\
\hline 8 & 100 & 2 & 2 & 10 & 0 & 0 & & \\
\hline 9 & 100 & 2 & 3 & 10 & 1 & 10 & & \\
\hline 10 & 1000 & 3 & 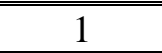 & 10 & 9 & 90 & \multirow{3}{*}{80} & \multirow{3}{*}{5,8416} \\
\hline 11 & 1000 & 3 & 2 & 10 & 8 & 80 & & \\
\hline 12 & 1000 & 3 & 3 & 10 & 7 & 70 & & \\
\hline
\end{tabular}

Berdasarkan Tabel 6, menunjukan bahwa pada pengujian BSLT, digunakan konsentrasi 0, 10, 100, dan 1000 ppm. Konsentrasi 0 ppm digunakan sebagai kontrol. Jumlah larva $A$. salina yang mati pada masing-masing konsentrasi akan memberikan nilai $\%$ mortalitas (perhitungan pada lampiran). Pengujian dilakukan 3 kali pengulangan sehingga didapatkan nilai rata-rata mortalitas. Dari nilai rata-rata mortalitas maka diperoleh nilai probit dengan melihat nilai probit pada tabel probit (Finney, 1971). Nilai probit yang diperoleh selanjutnya dimasukkan kedalam perhitungan persamaan regresi linier, sehingga didapatkan nilai $\mathrm{LC}_{50}$ (Lethal Concentration). Persamaan regresi linier didapatkan dari grafik hubungan nilai probit terhadap log konsentrasi ekstrak metanol alga hijau Boergesenia forbesii pada uji BSLT. Grafik hubungan nilai probit terhadap log konsentrasi ekstrak dapat dilihat pada Gambar 3. 


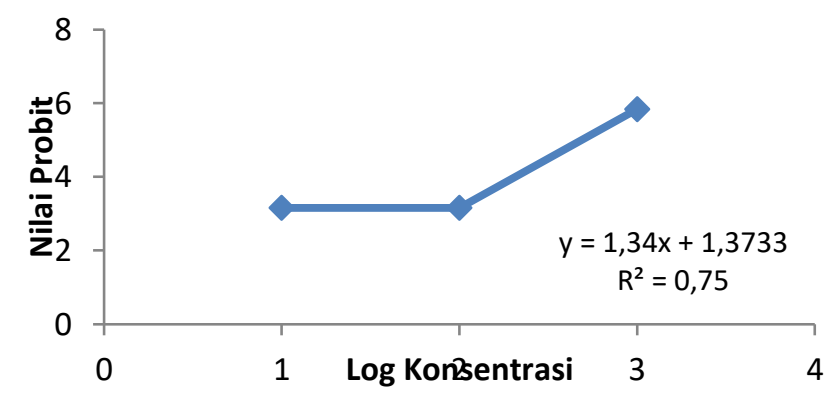

Gambar 3. Grafik hubungan nilai probit dengan log konsentrasi ekstrak metanol alga hijau Boergesenia forbesii pada uji BSLT

Dapat dilihat grafik pada Gambar 3, didapatkan persamaan $\mathrm{y}=1,34 \mathrm{x}+1,3733$, sehingga diperoleh nilai $\mathrm{LC}_{50}$ ekstrak metanol alga hijau Boergesenia forbesii sebesar 508,74 ppm (perhitungan pada lampiran). Menurut Meyer (1982), suatu ekstrak memiliki $\mathrm{LC}_{50}<1000 \mathrm{ppm}$ termasuk senyawa yang memiliki sifat toksik atau berpotensi sebagai antikanker dan kemampuan toksisitas suatu senyawa berkorelasi positif dengan aktivitas sitotoksiknya. Sehingga hal ini berarti bahwa ekstrak metanol alga hijau Boergesenia forbesii memiliki aktivitas sitotoksik yang berpotensi sebagai antikanker.

\section{Analisis GC-MS}

Identifikasi untuk menentukan profil senyawa antioksidan dalam alga Boergesenia forbesii dilakukan dengan menggunakan GC-MS terhadap ekstrak metanol alga hijau Boergesenia forbesii. GC-MS merupakan teknik analisis suatu senyawa aktif yang terdapat didalam senyawa kimia. Teknik analisis senyawa ini menggunakan 2 metode yaitu metode kromatografi gas (GC) dan spektrometri massa (MS). GC berfungsi sebagai menganalisis jumlah senyawa secara kuantitatif sedangkan MS berfungsi sebagai menganalisis struktur molekul senyawa analit. Hasil yang diperoleh berupa kromatogram yang ditunjukkan dengan suatu grafik dengan beberapa puncak, setiap satu puncak mewakili dari satu jenis senyawa.

Hasil kromatogram pada ekstrak metanol alga hijau Boergesenia forbesii diperoleh 28 puncak. Kromatogram GC ekstrak metanol alga hijau Boergesenia forbesii dapat dilihat pada Gambar 17 dan profil komponen kimia yang diperoleh dapat dilihat pada Tabel 5.

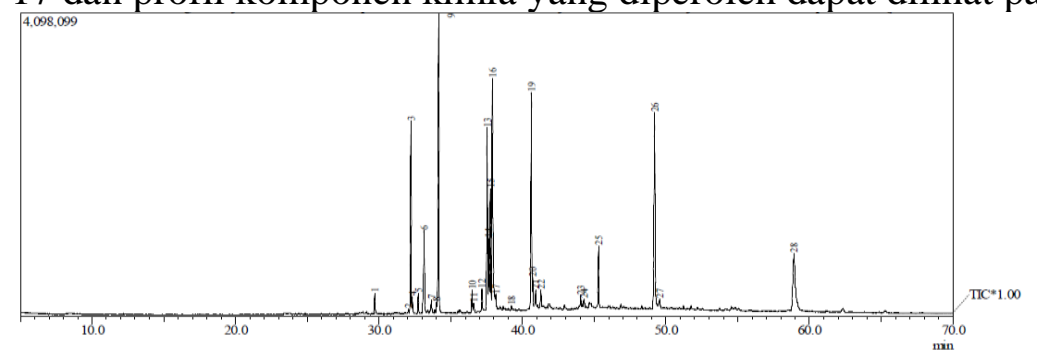

Gambar 4. Kromatogram GC ekstrak metanol alga hijau Boergesenia forbesii

Tabel 5. Komponen kimia yang teridentifikasi dalam ekstrak metanol alga hijau Boergesenia forbesii oleh GC-MS

\begin{tabular}{|c|c|c|c|}
\hline $\begin{array}{c}\text { no } \\
\text { peak }\end{array}$ & $\begin{array}{l}\text { waktu } \\
\text { retensi }\end{array}$ & $\begin{array}{l}\text { Are } \\
\text { a \% }\end{array}$ & Nama senyawa \\
\hline 1 & 29,692 & 0.92 & Methyl myristate \\
\hline 2 & 32,046 & 0.16 & 3-Tetradecene,(Z)- \\
\hline 3 & 32,224 & 7.74 & 1-Octadecyne \\
\hline 4 & 32,331 & 0.62 & Eicosyltrichlorosilane \\
\hline 5 & 32,733 & 0.81 & Tidak teridentifikasi \\
\hline
\end{tabular}




\begin{tabular}{|c|c|c|c|}
\hline $\begin{array}{c}\text { no } \\
\text { peak }\end{array}$ & $\begin{array}{l}\text { waktu } \\
\text { retensi }\end{array}$ & $\begin{array}{l}\text { Are } \\
\text { a \% }\end{array}$ & Nama senyawa \\
\hline 6 & 33,133 & 4.28 & Tidak teridentifikasi \\
\hline 7 & 33,658 & 0.56 & Palmitoleic Acid methyl ester \\
\hline 8 & 34,000 & 0.42 & Tidak teridentifikasi \\
\hline 9 & 34,150 & 13.61 & Methyl stearate \\
\hline 10 & 36,492 & 0.91 & 4-Hexadecen-6-yne, (E)- \\
\hline 11 & 36,600 & 0.39 & 1,5,9,11-Tridecatetraene, 12-methyl-(E,E)- \\
\hline 12 & 37,175 & 0.93 & Hexadecatrienoic acid methyl ester \\
\hline 13 & 37,533 & 8.32 & Methyl linoleate \\
\hline 14 & 37,642 & 2.85 & Tidak teridentifikasi \\
\hline 15 & 37,758 & 5.46 & Methyl (E)-octadec-11-enoate \\
\hline 16 & 37,900 & 13.21 & Phytol \\
\hline 17 & 38,133 & 0.82 & Tidak teridentifikasi \\
\hline 18 & 39,225 & 0.17 & Dodecanamide \\
\hline 19 & 40,617 & 10.09 & Methyl Arachidonate \\
\hline 20 & 40,717 & 1.22 & $\begin{array}{l}\text { 1-(2-Methylene-3-butenyl)-1-(1- } \\
\text { methylenepropyl)cyclopropane }\end{array}$ \\
\hline 21 & 40,908 & 0.80 & Tidak teridentifikasi \\
\hline 22 & 41,267 & 0.83 & Oleyl alcohol \\
\hline 23 & 44,050 & 0.45 & Tidak teridentifikasi \\
\hline 24 & 44,300 & 0.53 & Hexadecanoic acid 2,3bis[(trimethylsilyl)oxy]propyl ester \\
\hline 25 & 45,292 & 2.69 & DI-N-Octyl Phthalate \\
\hline 26 & 49,208 & 12.69 & 9-Octadecenamide, (z)- \\
\hline 27 & 49,567 & 0.82 & Squalene \\
\hline 28 & 58,908 & 7.72 & Dicholesteryl succinate \\
\hline
\end{tabular}

Identifikasi komponen kimia ekstrak metanol alga hijau Boergesenia forbesii dilakukan dengan membandingkan pola fragmentasi spektra massa hasil GC-MS dengan pola fragmentasi referensi (library) dari NIST12.LIB, WILEY229.LIB, dan NIST62.LIB. Senyawa yang dipilih adalah senyawa hasil penelusuran pustaka yang memiliki indeks kemiripan atau SI (Similarity Index) lebih besar sama dengan 90 dan dengan mempertimbangkan kesesuaian senyawa tersebut dengan komposisi serta sifat sampel asal. Luas area puncak kromatogram GC menunjukan konsentrasi relatif suatu senyawa terhadap sampel yang teruapkan saat pengoperasian GC-MS. Pada kromatogram GC terdapat 4 puncak dengan nilai \% luas area yang lebih besar dibandingkan dengan yang lainnya, sehingga 4 puncak tersebut merupakan komponen utama di dalam ekstrak metanol alga hijau Boergesenia forbesii, yaitu Methyl Stearate (no 9), Phytol (no 16), Methyl Arachidonate (no 19), dan 9-Octadecenamide,(z)- (no 26). Telah dilaporkan bahwa Metyl Stearate memiliki aktivitas sebagai antikanker (Hady et al., 2017), Phytol 
memiliki aktivitas sebagai antioksidan (Syad et al., 2016), antikanker (Laksmi et al., 2016), dan antimikroba (Kumar et al., 2010), Methyl Arachidonate memiliki aktivitas sebagai vascular reactivity (Hady et al, 2017), dan 9-Octadecenamide,(z)- memiliki aktivitas sebagai anti inflammatory dan anti bakteri (Idan et al., 2015). Selain senyawa mayor terdapat juga senyawa minor di dalam ekstrak metanol alga hijau Boergesenia forbesii yang diketahui memiliki aktivitas sebagai antioksidan yaitu Squalene $\left(\mathrm{IC}_{50}=23\right.$ ppm) (Spanova et al., 2011 dan Amarowicz, 2009).

\section{KESIMPULAN DAN SARAN}

Dari hasil penelitian ini dapat diambil beberapa kesimpulan bahwa hasil uji Aktivitas antioksidan ekstrak metanol alga hijau Boergesenia forbesii dengan menggunakan metode DPPH diperoleh nilai $\mathrm{IC}_{50}$ sebesar $585,79 \mathrm{ppm}$, sedangkan asam galat yang digunakan sebagai kontrol positif memiliki nilai $\mathrm{IC}_{50}$ sebesar $3,13 \mathrm{ppm}$, yang menunjukkan bahwa aktivitas antioksidan ekstrak metanol alga hijau Boergesenia forbesii sangat lemah, dibandingkan dengan asam galat (kontrol positif) memiliki aktivitas antioksidan yang sangat kuat.

Hasil uji BSLT ekstrak metanol alga hijau Boergesenia forbesii diperoleh nilai $\mathrm{LC}_{50}$ sebesar 508,74 ppm yang menunjukkan bahwa ekstrak tersebut mengandung senyawa yang bersifat toksik sehingga berkorelasi positif terhadap sitotoksisitasnya yang berarti bahwa ekstrak metanol alga hijau Boergesenia forbesii memiliki potensi sebagai antikanker.

Hasil GC-MS dari ekstrak metanol alga hijau Boergesenia forbesii didapatkan 28 senyawa, 6 diantaranya belum teridentifikasi. Diperoleh 4 senyawa utama (mayor) yaitu Methyl Stearate, Phytol, Methyl Arachidonate, dan 9-Octadecenamide,(z), yang diketahui Phytol dan Methyl Sterate merupakan senyawa aktif sebagai antioksidan dan antikanker. Selain itu, diperoleh 18 senyawa minor, salah satu diantaranya diketahui memiliki aktivitas antioksidan yaitu Squalene.

\section{Saran}

Perlu diteliti lebih lanjut uji antioksidan dengan menggunakan metode lain dan metode ekstraksi menggunakan pelarut non polar. Selain itu, perlu dilakukan pengujian antioksidan dan sitotoksisitas terhadap fraksi polar dan non polar.

\section{DAFTAR PUSTAKA}

Alam G., dan Rahim A., 2006. Buku Pegangan Laboratorium Fitokimia I, Laboratorium Farmakognosi-Fitokimia. Makassar: Universitas Islam Negeri Alauddin.

Almatsier S. 2003. Prinsip Dasar Ilmu Gizi. Jakarta: PT. Gramedia Pustaka Utama.

Amarowicz R. 2009. Editorial Squalene: A natural antioxidant? Eur.J.Lipid Sci. Technol, 111, pp. 411-412.

Badarinath A.V., Rao K., Chetty C., Ramkanth S., Rajan T., Gnanaprakash K. 2010. A Review on In-vitro Antioxidant Methods: Comparisions, Correlations and Considerations. International Journal of PharmTech Research, 2(2), pp. 12761285.

Ballantine D.L., Ohba H., Troche L.C., Ruiz H. 2011. Boergesenia parvula sp. nov. (Siphonocladales, Chlorophyta) from the Tropical Western Atlantic. BioOne Research Evolved, 32(4), pp. 327-336.

Boonchum W., Peerapornpisal Y., Kanjanapothi D., Pekkoh J., Pumas C., Jamjait U., Amornlerdpison D., Noiraksar T., Vacharapiyasophon P. 2011. Antioxidant Activity of some Seaweed from The Gulf of Thailand. International Journal of Agriculture and Biology, 13(1), pp. 95-99.

Budhiyanti A., Raharjo S., Marseno D., Lelana I. 2012. Antioxidant Activity Of Brown 
Algae Sargassum Species Extract from The Coastline of Java Island. American Journal of Agricultural and Biological Science, 7(3), pp. 337-346.

Carballo J.L., Inda Z.L., Perez P., Gravalos M. 2002. A Comparison Between Two Brine Shrimp Assays to Detect In Vitro Cytotoxicity In Marine Natural Products. BMC Biotechnology, 2(17), pp. 1-5.

Chakraborty K., dan Paulraj R. 2010. Sesquiterpenoids With Free-Radical-Scavenging Properties from Marine Macroalga Ulva Fasciata Delile. Food Chemistry, Elsivier,122(1), pp. 31-41.

Cornish M. L., dan Garbary D. J. 2010. Antioxidants from Macroalgae: Potential Applications in Human Health and Nutrition. Algae, 25(4), pp. 155-171.

Cox S., Abu-Ghannam N., Gupta S. 2010. An Assessment of The Antioxidant and Antimicrobial Activity of Six Species of Edible Irish Seaweeds. International Food Research Journal, 17(1), pp. 205-220.

Christiana R., Kristopo H., Limantara L. 2008. Photodegradation and Antioxidant Activity of Chlorophyll a from Spirulina (Spirulina $s p$ ) Powder. Indo. J .Chem, $8(2)$, pp. 236-241.

Dachriyanus. 2004. Analisis Struktur Senyawa Organik Secara Spektroskopi. LPTIK, Universitas Andalas

Davey, P. 2006. At a Glance Medicine. Jakarta: Erlangga.

Departemen Kesehatan Republik Indonesia. 1979. Farmakope Indonesia, Edisi III. Jakarta : Derektoral Jenderal Pengawasan Obat Dan Makanan.

Febriyanti, T., Andayani, D.R., Jos, B. 2004. Peningkatan Mutu Light Cycle Oil (LCO) Dengan Cara Ekstraksi Cair-cair Menggunakan Solvent Dimethylformamide (DMF). Laporan Penelitian. Semarang: Fakultas Universitas Diponegoro.

Finney D.J. 1971. Probit Analysis. 2nd Edition. Canbridge University. Press. 250

Flanaga, RJ., Braithwaite R.A.Brown S.S., Widdop B., de Wolff F.A. 1995. Basic Analytical Toxicology. World Healt Organization. Geneval, 85.

Gazali M., Zamani N.P., Nurjanah. 2019. The Potency of Green Algae Chaetomorpha crassa Agardh as Antioxidant Agent from the Coastal of Lhok Bubon, West Aceh. IOP Conference Series: Earth and Environmental Science, 278

Gritter R. J., M. B James, E. S. Arthur. 1991. Pengantar Kromatografi. Institut Teknologi Bandung, Bandung. (diterjemahkan oleh Kosasih Padmawinata).

Guiry M.D. 2018. Boergesenia forbesii (Harvey) Feldmann, AlgaeBase.

Gupta S., dan Abu-Ghannam N. 2011. Bioactive Potential and Possible Health Effects of Edible Brown Seaweeds. Trends in Food Science and Technology, Elsevier, 22(6), pp. 315-326.

Hady H., Gawad M., Wakil E. 2017. Characterization and Evaluation of Antioxidant Activity of Ocimum canum Leaves and Its Effeciency on Schistosoma mansoni Larval Stage. Indo American Journal of Pharmaceutical Research, 7 (11), pp. 978994

Halliwell B. 2007. Oxidative Stress and Cancer: Have We Moved Forward?, Biochemical Journal, 401(1), pp. 1-11.

Harborne, J. B. 1987. Metode Fitokimia : Penuntun Cara Modern Menganalisis Tumbuhan. Institut Teknologi Bandung, Bandung. (diterjemahkan oleh Kosasih Padmawinata dan Iwang Soediro).

Heo S., Cha S., Lee K., Cho S., Jeon Y. 2005. Antioxidant Activities of Chlorophyta and Phaeophyta from Jeju Island. Algae, 20(3), pp. 251-260.

https://pariwisata.bengkuluprov.go.id, diakses pada tanggal 26 Juni 2018.

Idan S., Marzoqi A., Hamed I. 2015. Spectral Analysis and Anti-bacterial Activity of Methanolic Fruit Extract of Citrullus colocynthis using Gas ChromatographyMass Spectrometry. African Journal of Biotechnology, 14(46), pp. 3131-3158. 
Juniarti, Osmeli D., Yuhernita. 2009. Kandungan Senyawa Kimia, Uji Toksisitas (Brine Shrimp Lethality Test) dan Antioksidan (1,1-Diphenyl-2-Pikrilhydrazyl) dari Ekstrak Daun Saga (Abrus Precatorius L.). Macara Sains, 13(1), pp. 50-54.

Kumar P., Kumaravel S., Lalitha C. 2010. Screening of Antioxidant Activity, Total Phenolics and GC-MS Study of Vitex negundo. African Journal of Biochemistry Research, 4(7), pp. 191-195.

Khopkar, S.M. 1990. Konsep Dasar Kimia Analitik. Jakarta: UI-Press. Halaman. 146.

Krishnaraju A V., Rao T., Sundadaraju D., Vanisree M., Tsay H., Subbaraju G. 2005. Assessment of Bioactivity of Indian Medicinal Plants Using Brine Shrimp (Artemia Salina) Lethality Assay. International Journal of Applied Science and Engineering, 3(2), pp. 125-134.

Kuda T., Kunii T., Goto H., Suz Suzuki T., Yano., T. 2007. Varieties of Antioxidant and Antibacterial Properties of Ecklonia Stolonifera and Ecklonia Kurome Products Harvested and Processed in the Noto Peninsula, Japan. Food Chemistry, Elsevier, 103(3), pp. 900-905.

Lakshmi S., Bharadwaj S., Parveen K. 2016. Anticancer Activity of Phytol Purified from Gracilaria edulis Against Human Breast Cancer Cell line (MCF-7). International Journal Current Science, 19(4), pp. 36-46.

Lu Y., Shipton F.N., Khoo T.J., Wiart C. 2014. Antioxidant Activity Determination of Citronellal and Crude Extracts of Cymbopogon citratus by 3 Different Methods. Pharmacology and Pharmacy, 5, pp. 395-400.

Maheswari, M. U., Reena A., Sivaraj C. 2017. GC-MS Analysis, Antioxidant and Antibacterial Activity of The Brown Algae, Padina Tetrastromatica. International Journal of Pharmaceutical Sciences and Research, 8(9), pp. 4014-4020.

Mailiza, A. 2019. Penentuan Aktivitas Antioksidan dan Antibakteri Ekstrak Metanol Boergesenia forbesii (Harvey) Feldmann dan Canavalia rosea (SW) DC yang Berasal dari Pantai Bengkulu. Tesis. Fakultas Matematika dan Ilmu Pengetahuan Alam. Universitas Bengkulu.

Maisuthisakul P., Pasuk S., \& Ritthiruangdej P. 2008. Relationship Between Antioxidant Properties and Chemical Composition of some Thai Plants. Journal of Food Composition and Analysis, 21(3), 229-240.

Marraskuranto E., Fajarningsih N., Januar H., Wikanta T. 2008. Aktivitas Antitumor (HeLa dan T47D) dan Antioksidan Ekstrak Makroalga Hijau Ulva fasciata. Jurnal Pascapanen dan Bioteknologi Kelautan dan Perikanan, 3(2), pp. 107-112.

Mclaughlin J. L., Rogers, L. L. dan Anderson, J. E. 1998. The Use of Biological Assays to Evaluate Botanicals. Drug Information Journal, 32(2), pp. 513-524.

Meyer B. Ferrignni N., Putnam J., Jacobsen L., Nichols D., Mclaughlin J. 1982. Brine Shrimp: A convenient General Bioassay for Active Plant Constituents. Journal of Medicinal Plant Research, 45, pp. 31-34.

Miliauskas G., Venskutonis P.R., Beek T.A. 2004. Screening of Radical Scavenging Activity of some Medicinal and Aromatic Plant Extracts. Food Chemistry, Elsiever, 85, pp. 231-237.

Molyneux P. 2004. The Use of the Stable Free Radical Diphenylpicryl-hydrazyl (DPPH) for Estimating Antioxidant Activity. Songklanakarin Journal of Science and Technology, 26(2), pp. 211-219.

Nabavi S.F., Nabavi S.M., Ebrahimzadeh M.A., Jafari N., Yazdanpanah S. 2013. Biological Activities of Freshwater Algae, Spirogyra singularis Nordstedt. Journal of aquatic food product technology, 22(1), 58-65.

Noegrohati. 1996. Prinsip Dasar dan Aplikasi Kromatografi Gas. Yogyakarta: Laboratorium Analisa Kimia dan Fisika Pusat Universitas Gadjah Mada.

Nurhayati Awik P., Abdulgani Nurlita., Febrianto Rachmat. 2006. Uji Toksisitas Ekstrak 
Eucheuma Alvarezii terhadap Artemia Salina sebagai Studi Pendahuluan Potensi Antikanker. Akta Kimindo, 2(1), pp. 41-46.

Nurmiyati. 2013. Keragaman, Distribusi dan Nilai Penting Makro Alga di Pantai Sepanjang Gunung Kidul. Bioedukasi, 6(1), pp. 12-21.

Ozben, T. 2007. Oxidative Stress and Apoptosis: Impact on Cancer Therapy. Journal of Pharmaceutical Sciences, 96 (9), pp. 2181-2196.

Pemerintah Provinsi Bengkulu Dinas Energi dan Sumber Daya Mineral. 2012. Informasi Potensi Sumber Daya Mineral, Batuan, Batubara dan Panas Bumi Provinsi Bengkulu: Bengkulu.

Pisutthanan S, Plianbangchang P., Pisutthanan N., Ruanruay S., Muanrit O. 2004. Brine Shrimp Lethality Activity of Thai Medicinal Plants in the Family Meliaceae. Naresuan University Journal, 12(2), pp. 13-18.

Pratt D.E., dan Hudson B.J. 1990. Natural Antioxidants Not Exploited Commercially. In Food antioxidants, Springer, Dordrecht, pp. 171-19.

Purwanto, Sigit. 2015. Uji Aktivitas Antibakteri Fraksi Aktif Ekstrak Daun Senggani (Melastoma malabathricum L) terhadap Escherichia coli. Jurnal Keperawatan Sriwijaya, 2 (2)

Rezaeizadeh A., Zuki A.B.Z., Abdollah, M., Goh Y.M., Noordin M.M., Hamid M., Azmi T.I. 2011. Determination of Antioxidant Activity in Methanolic and Chloroformic Extracts of Momordica charantia. African Journal of Biotechnology, 10(24), pp. 4932-4940.

Rohman, A. 2016. Validasi dan Penjaminan Mutu Metode Analisis Kimia.Yogyakarta: Gadjah Mada University Press. Hlm. 150.

Rosalina R. 2009. Efek Rumput Laut Eucheuma sp. Terhadap Kadar Glukosa Darah dan Jumlah Monosit Pada Tikus Wistar yang Diinduksi Aloksan. Skripsi. Universitas Diponegoro.

Saeidnia S., Permeh P., Gohari A., Moradi A.. 2012. Gracilariopsis persica from Persian Gulf Contains Bioactive Sterols. Iranian Journal of Pharmaceutical Research, 11(3), pp. 845-849.

Sari, Rizka F. 2011. Kajian Potensi Senyawa Bioaktif Spirulina platensis sebagai Antioksidan. Skripsi. Fakultas Perikanan dan Ilmu Kelautan. Universitas Diponegoro Semarang.

Sastrohamidjojo H. 2001. Spektroskopi. Yogyakarta: Penerbit Liberty.

Setiawati T., Nurzaman M., Mutaqin A., Budiono R., Abdiwijaya A. 2017. Kandungan Vitamin C dan Potensi Makroalga di Kawasan Pantai Cigebang, Cianjur, Jawa Barat. Pros Sem Nas Masy Biodiv Indon, 3(1), pp. 39-44.

Shahidi F., dan Naczk M. 1995. Food Phenolics. Technomic pub. Co. Inc. LancesterBasel.

Suhartati T. 2013. Dasar-dasar Spektrofotometri UV-Vis dan Spektrofotometri Massa Untuk Penentuan Struktur Senyawa Organik. AURA, CV. Anugrah Utama Raharja

Spanova M., Daum G. 2011. Squalene-Biochemistry, Molecular Biology, Process Biotechnology, and Applications. European Journal of Lipid Science and Technology, 113(11), pp. 1299-1320.

Sumarno. 2001. Kromatografi: Teori Dasar dan Petunjuk Praktikum. Yogyakarta: Fakultas Farmasi Universitas Gadjah Mada.

Syad A.N., Rajamohamed B.S., Shunmugaiah K.P., Kasi P.D. 2016. Neuroprotective Effect of the Marine Macroalga Gelidiella acerosa: Identification of Active Compounds through Bioactivity-Guided Fractionation. Pharmaceutical biology, 54(10), pp. 2073-2081.

Syarifuddin dan Supriati, R. 2009. Inventarisasi Jenis Makroalga di Pesisir Pantai Kota 
Bengkulu. Makalah. Dipresentasikan pada Seminar dan Rapat Tahunan Bidang Ilmu MIPA Badan Kerjasama PTN Wilayah Barat (SEMIRATA BKS-PTN B).

Tamat S.R., Wikanta T., Maulina L. S. 2007. Aktivitas Antioksidan dan Toksisitas Senyawa Bioaktif dari Ekstrak Rumput Laut Hijau Ulva reticulata Forsskal. Jurnal Ilmu Kefarmasian Indonesia, 5(1), pp. 31-36.

Tristantini D., Ismawati A., Pradana B. T., Jonathan, J. G. (2016). Pengujian Aktivitas Antioksidan Menggunakan Metode DPPH pada Daun Tanjung (Mimusops elengi L). In Seminar Nasional Teknik Kimia Kejuangan (p. 1).

Wikanta T., Januar H.I., Nursid M. 2005. Uji Aktivitas Antioksidan, Toksisitas, dan Sitotoksisitas Ekstrak Alga Merah Rhodymenia palmata. Jurnal Penilitian Perikanan Indonesia, 11(4), pp. 41-49.

Wikanta T., Zakaria Y.A., Ratih D., Nursid M. 2007. Uji Aktivitas Sitotoksik Ekstrak Karang Lunak Sarcophyton glaucum (Quoy \& Gaimard) Terhadap Sel Lestari Tumor HeLa. Balai Besar Riset Pengolahan Produk dan Bioteknologi Kelautan dan Perikanan, Jakarta.

Wikanta T., Damkayanti R., Rahayu L. 2008. Pengaruh Pemberian K-Karagenan Dan 'IKaragenan Terhadap Penurunan Kadar Glukosa Darah Tikus Hiperglikemia. Jurnal Pasca Panen dan Bioteknologi Kelautan dan Perikanan, 3(2), pp. 131-138.

Wikanta T., Prabukusuma A., Ratih D., Januar, H.I. 2010. Bioaktivitas Ekstrak Kasar Aseton, Fraksi, dan Subfraksinya dari Ulva fasciata Terhadap Sel Lestari Tumor Hela. Jurnal Pascapanen dan Bioteknologi Kelautan dan Perikanan, 5(1), pp. 19.

Winarsi H. 2007. Buku Antioksidan alami \& radikal bebas. Yogyakarta: Kanisius.

Wu S. C., Wang F.J., Pan C.L. 2010. The Comparison of Antioxidative Properties of Seaweed Oligosaccharides Fermented By Two Lactic Acid Bacteria. Journal of Marine Science and Technology, 18(4), pp. 537-545.

Zubia M., Robledo D., Freile-Pelegrin Y. 2007. Antioxidant Activities in Tropical Marine Macroalgae from The Yucatan Peninsula, Mexico. Journal of Applied Phycology, 19(5), pp. 449-458. 